\title{
Implementation of the Precautionary Principle within Prerogative Power to Overcome the Threat of Financial Crisis
}

\author{
Kukuh Komandoko \\ Faculty of Law, University of Indonesia, Depok 16424, Indonesia
}

\begin{abstract}
A crisis or depression, one significant unfortunate event, often happens without warning or preparation and cannot be ignored. Likewise, the threat of a financial crisis is a risk that concerns dangers in a state's economic and political stability. A financial crisis may cause a market and public panic that brings irrational actions. If not prevented or mitigated immediately, a financial crisis can cause a state's economic and political stability to collapse. It becomes very dangerous if the state does not have normative rules governing financial crisis prevention and mitigation. In this case, the president, as the head of the executive, must take a prerogative power to prevent or mitigate the financial crisis. This is the background of why a precautionary principle is needed in prerogative power when dealing with a financial crisis. The precautionary principle is used to deal with emergency hazards in the environmental fields, but lately, it has been widely used in many fields, including biotechnology and health. In general, the precautionary principle is understood as making decisions in encountering threats or situations that are dangerous and uncertain. With the background of Indonesia's empirical experience in overcoming the financial crisis of 1997-1998, this article will focus on the notion of implementing the precautionary principle within prerogative power and its prospects to overcome the threat of financial crises.
\end{abstract}

Keywords: banking crisis, financial crisis, precautionary principle, prerogative power, state of emergency

DOI: $10.7176 /$ JLPG/105-10

Publication date: January $31^{\text {st }} 2021$

\section{Introduction}

With the main background of the 1997-1998 financial crisis in Indonesia, it is interesting to examine whether the precautionary principle's conceptual elements have been applied. Precautionary principle has its own place in the legal system, in general, the precautionary principle is understood as an approach in making decisions to face dangerous and uncertain situations (Ellis and FitzGerald 2004). In its development, the European Union promoted the precautionary principle as the basis for making decisions on environmental policies and other areas, such as trade. In this regard, the European Union supports the idea that regulatory measures should be taken immediately, even when the threat of harm is uncertain, even when it is highly speculative. Applying this principle, in whatever form and scope, can significantly influence the strategies and policies that are the result of decision making, especially to assist decision making in difficult situations (Sunstein 2005b).

The precautionary principle's main objective is to act prudently in the face of threats of uncertainty before serious (or even irreparable) damage occurs (Lauridsen 2013). Initially, the precautionary principle is a basic principle in preventing environmental issues, namely protecting from possible hazards that have not been scientifically proven. In practice, the precautionary principle application has expanded not only in the field of environmental protection but includes the fields of sustainable development, health, trade, and food safety. In economics-sustainable development, the precautionary principle is seen as an integral principle of ethical ideas about justice and between generations, which sees development as a whole (United Nations Educational Scientific and Cultural Organization 2005).

The 1997-1998 financial crisis was the worst in Indonesia's history, preceded by the Thai financial crisis, which later spread to several countries in Asia. The problems at that time were very complex. Indonesia did not yet have adequate legal and institutional instruments to prevent or handle the threat of crisis. The applied laws and regulations in the financial sector were very limited and inefficient in its implementation. This situation creates problems and gaps between the governing regulations and an emergency need.

Without adequate legal and institutional instruments to guide the threat of crisis, the government tried to prevent it from worsening. To prevent the situation from worsening, the government tried to restore macroeconomic stability and a credible financial system. The government tried to resolve problematic financial institutions, strengthens viable financial institutions, manages assets, and undertakes corporate restructuring. The government also asked for assistance from the International Monetary Fund (IMF) and immediately restructuring private companies and banks (Martinez-Diaz 2006). One of the IMF's involvement was the process of closing 16 private commercial banks (International Monetery Fund 1997). This empirical experience shows how the government acted for the state's interest without an applicable legal framework to deal with the crisis's threat. The existing financial or banking regulations could not answer all the needs at that time. However, the absence of qualified legal norms should not be an obstacle to reacting and acting to deal with the crisis threat. In this case, the government was using its prerogative power as an executive for state good. 
This article will discuss the notion of applying the precautionary principle within prerogative power, especially in overcoming the threat of a financial crisis. First, the article will discuss the precautionary principle. Second, the discussion will shortly discuss Indonesia's financial crisis of 1997-1998. Third, it will elaborate on the legal gaps that happened in Indonesia's financial crisis. Fourth, discussing the concept of how to apply the precautionary principle within prerogative power in overcoming the threat of financial crisis.

\section{The Discourse of the Precautionary Principle}

\subsection{Transformation}

The precautionary approach method was first used in London in 1854 by a doctor named John Snow, who investigated the relationship between water supplies and the cholera epidemic. From what he had investigated and studied, Snow created the first epidemiological map of the disease and its possible causes, presented to the Epidemiological Society of London on 4 December 1854 (Brody et al. 2000). What John Snow had done was a precautionary approach to uncertainty. Although the relation between polluted water and cholera was not scientifically proven, the London city government still decided to shut down its water pumps based on Snow's recommendation. A biological event regarding the relation between polluted water and cholera was only proven 30 years later by Robert Koch in connection with the discovery of vibrio cholera in Germany (Harremoes et al. 2001). While Snow was unable to prove his theory at the time, the results obtained from his research were sufficient evidence for Snow to recommend a course of action.

The precautionary approach was becoming a principle in resolving environmental problems. To minimize the risks faced in environmental problems, the German government came up with a notion called Vorsorgeprinzip. The Vorsorgeprinzip or the Vorsorge Principle is the main principle, fundamental for the German Government to address environmental problems. The idea is decisive action to minimize the risks faced in environmental problems. In Vorsorgeprinzip, there is the concept of Gefahrenvorsorge, which is translated into a risk precaution or understood as a precautionary measure in the context of "prevention of risk." The concept is to protect from possible hazards that have not been scientifically proven. Immediate preventive action is taken from hazards spatially or temporarily, including possible hazards that have not been scientifically proven and burdens on the environment that are not harmful in themselves but dangerous when combined with other pollutants. Overall, the idea of Vorsorgeprinzip is a preventive measure that tries to avoid serious damage (Cameron and Abouchar 1991). The term precautionary principle is actually a translation of the phrase Vorsorgeprinzip, which was echoed around 1970 in Germany and later used in German Environmental Protection in 1974. However, Cross argues that the precautionary principle was first used in 1965 on the German Administrators Committee (Cross 1996). while in the same period, Sweden has used the general precautionary principle in Swedish Environmental Protection Act of 1969 (Sunstein 2005a).

\subsection{Various Definition and Perspectives}

Until now, there has been no agreement from scholars regarding the standard definition of the precautionary principle. Many scholars are still debating the understanding of the precautionary principle. This can be seen from the many different definitions of the precautionary principle in international conventions, declarations, and documents. This complicates the determination of the exact definitions regarding the precautionary principle (Vanderzwaag 2002). Likewise, with references to damage or danger or threats from different precautionary principles, adding to the difficulty of making a formal definition. Such as the precautionary principle formulation concerning damage or harmful effects. In other references, there are precautionary principles that focus on serious damage, and some refer to serious and irreversible damage. There are even references that focus on global destruction. Besides, there are precautionary principles concerning cost-effective measures or even have other references for costs (Weiss 2003). In terms of practice, the precautionary principle has been included in international legal documents. The term precautionary principle has been used widely, referring to principles that have been generally applied by decision-makers and policies. In that case, the precautionary principle is understood as an action that may have to be taken against a hazard, even though the available evidence is insufficient to make the existence of the hazard a scientific fact. Thus, preconditioned conditions emphasize the principle of decisionmaking that can be justified, either on a moral or precaution basis (Sandin 2002). This section will discuss some definitions and perspectives from scholars regarding the precautionary principle.

The various definition, formulation, and reference are the precautionary principle's version of nature, perhaps a unique characteristic of the precautionary principle. Some scholars even make their own version from a different perspective. Wiener and Rogers, distinguishes the precautionary principle in three versions (Wiener and Rogers 2002). Version 1 described by Wiener and Rogers with the term uncertainty does not justify inaction or uncertainty does not justify delaying or inaction. Version 2 is described as more aggressive with the term uncertainty justifies action, or uncertainty is a justification of action, and version 3 is uncertainty requires shifting the burden and standard of proof or shifting the burden of evidence.

From the identification made by Dinnen, there are at least 19 versions of the precautionary principle definition. 
At the basic level is the definition as a principle of public decision making. When there is a 'threat' of environmental or health damage, it will not use 'scientific uncertainty' as an excuse for not taking preventive action (Fisher et al. 2006). Apart from that, Dinnen agrees with the 3 (three) versions of the precautionary principle, according to Wiener and Rogers' understanding. In addition to definitions, in his research, Dinnen also expressed the different perspectives between European Communities and the United States of the precautionary principle. For European Communities, the precautionary principle is seen as one of the general principles in international law. At the same time, the United States believes that the precautionary principle is not a general principle in international law, but as an 'approach' that varies according to situations and contexts (Dinneen 2013).

Unlike the previous scholars, Gollier and Treich tried to describe an economic-based understanding of the precautionary principle. Gollier and Treich's research and understanding of the work is based on cost-benefit analysis, where there is scientific uncertainty about both costs and benefits (Gollier and Treich 2003). Besides, the irreversibility effect makes the precautionary principle more flexible and can be perceived as an incentive or even an obstacle to information generated by scientific advances in the decision-making process. In an asymmetric information situation, the precautionary principle can be used as a protection tool, especially for those who seek profit from the situation (Gollier and Treich 2003). Of all the understanding and definitions of the precautionary principle, Sunstein offered the simplest, namely, "it is better to be safe than sorry." Applying this principle, in whatever form and scope, can significantly influence the strategies and policies that are the result of decision making, especially to assist decision making in difficult situations (Sunstein 2005b). However, Sunstein remind that whoever most fearful and keen to avoid danger, often escalate risks through their efforts to rule out the danger. People lean to be fear and may take foolish precautions (Sunstein 2005a). Sunstein concludes that the precautionary principle will become far less helpful when we see that risks are inevitably parts of systems (Sunstein 2005a). Henceforth, Sunstein reconstructed the precautionary principle in three dimensions. The first involves catastrophic risks, the second involves irreversible harms, and the third involves margins of safety for risks that, while not potentially catastrophic, pose distinctive reasons for concern.

\subsection{Uncertainty and precautionary principle}

Since its adoption by the UN General Assembly in 1982, the precautionary principle's use and development have grown in popularity. In practice, the precautionary principle brings significant changes to the decision-making process to deal with critical situations and conditions that arise from a dangerous threat. Including if the risk of these dangerous threats is not visible or fully measurable because of inadequate scientific data. The precautionary principle provides guidance, helping decision-makers to decide and respond to the dangerous threat, even though there is the uncertainty caused by information and scientific certainty needed is not provided. Ideally, when implementing the precautionary principle, analysis and evaluation should be carried out in advance of all data related to the threats. There are important factors that must be done before deciding to respond, namely identifying the threat and damage that is likely to occur. In this case, identification is carried out through reliable scientific methods that consider the risk of uncertainty.

For decision-makers, uncertainty is a factor that must be understood with different meanings, depending on the context. Uncertainty can be caused by case variables, calculations, and causal relationships. Uncertainty also often arises when data is not valid and reliable. All the symptoms of each case (including the risk of uncertainty) should be managed and classified according to science. With a highly context-dependent variation, it makes uncertainty difficult to understand, this often creates fear and hesitation. Almost all understanding and perceptions regarding the uncertainty are always associated with risk factors. So important is the uncertainty that Keynes described as a roulette game, and Schomberg said that scientific uncertainty is essential in understanding how and why the precautionary principle is applied. Uncertainty will always overshadow every event, even when we are aware of the possible dangers that threaten us. In general, in the author's opinion, uncertainty is an unknown situation with a lack of conviction, which is critical to be considered in the precautionary principle.

In response to this, scholars think it is better to focus on risk. However, in most cases, scientific data are not sufficient to apply the precautionary principle. These circumstances can make decision-makers hesitate to respond or not, and uncertainty is not a justification for not respond. In other words, you are in "to be or not to be" circumstances. From the author's perspective, uncertainty coupled with fear causes hesitation and interferes with your judgment.

\subsection{Basics understanding of precautionary principle}

To understand and define the precautionary principle, some scholars have tried to elaborate on the basics understanding of precautionary principles. Based on specific notions and exploration, most of them have the same basic understanding concerning the principle. The same basic understanding includes the elements:

First, there is a dangerous threat, which is in some versions, is understood to be irreversible, damaging, or a serious effects, as defined in the London Declaration, Rio Declaration, and the 1992 Paris Convention. It can be understood that the precautionary principle is a principle that applies to certain threats with extraordinary damage 
effects. Second, there is uncertainty, or a lack of scientific evidence, which is understood as a situation where there is a lack of or no knowledge and a lack of information on a threatening hazard. The uncertainty can be in any situation, including causes of threats, impacts, cause-and-effect relationships, and long-term consequences (DeFur and Kaszuba 2002). Third, whatever the context, the action taken is more of a preventive nature. The cases' form and scope can significantly influence strategies and policies to be taken, especially in difficult and danger circumstances. The precautionary principle can be considered as a limitation or starting point for triggering preventive action (Wibisana 2011). Fourth, an obligation to respond. The threat and uncertain circumstances should not make the authorities release from their responsibility to respond to overcome the threat of danger.

Out of the description above, it appears that there is no definition of the precautionary principle that has been universally accepted. The divergences in law, social, cultural, and political values influence the scholars' perspectives. Although there is no universal definition of the precautionary principle, it does not mean the various versions and definitions have nothing in common. Bourguignon argues that the precautionary principle has a common denominator, namely to avoid adverse impacts in scientific uncertainty situations (Bourguignon 2015). From the author's perspective, the precautionary principle is unique and has at least three significant roles in common that most supporters of the precautionary principle generally fit. First, as an approach to avoid the serious damage or dangerous risks due to a threat. Second, as a response to uncertain critical situations. Third, as a guide in dealing with a catastrophic state.

However, the precautionary principle also has some controversial perspectives and, therefore, not without some criticism. As one critic stated by Sabhlok, the precautionary principle gives bureaucrats the freedom to only count benefits, ignore costs, or only count imagined cost while ignoring benefits (Sabhlok 2019). Furthermore, the principle reverses the burden of proof of harm for regulatory intervention and taking us to the dark ages (Sabhlok 2019). Therefore Sabhlok rejects the precautionary principle and suggests using the standard cost-benefit test. Another criticism of the precautionary principle was argued by Martin Peterson. Peterson argues that the precautionary principle should not be used by itself as a basis for decision making, since no formulation of the precautionary principle can be consistent with three fundamental principles of rational decision-making. Also, according to him, the precautionary principle is unreasonable qualitative decision rule (Peterson 2007).

Sabhlok and Paterson's can be both right, since the precautionary principle is unique and has its own way of looking at each different problem. This is indicated by the many definitions and versions of the precautionary principle used in international documents or provisions. In this case, any weakness of the precautionary principle shall lead toward a worthwhile notion of completing the precautionary principle in facing the uncertain, hazardous threat.

\subsection{The development of precautionary principle}

In the beginning, the precautionary principle was originally only to deal with health problems and environmental protection. Over time, with increasing human needs, the more sophisticated technology, and science, the precautionary principle has evolved into a principle not only for conducting risk assessments on health and the environment. The precautionary principles were also developed as an approach to the decision-making process, and their application is starting to expand, including Genetically Engineered Products.

During its development, the precautionary principle was also discussed concerning nanomaterials' engineering, that recommended for prohibition from food products by the United States National Organic Standards Council. The discussion concerned whether the food production is safe before being marketed and implicitly stated that the precautionary principle with certain criteria could be used as a guide in conducting research and policymaking (Kessler 2011). This means that the precautionary principle can function as a framework, as guidance in the decision-making process and the discussion provides an update of the precautionary principle. The principle develops into a general framework for the entire series of policies.

Interestingly, the latest development is expanding the precautionary principle concept to become a Universal Precautionary Principle (UPP), which recognizes the relationship between society and land, elevating people's welfare, culture, and the economy as values that are as important as environmental issues (Akins et al. 2019). The UPP is context-dependent in its implementation and consists of three domains: the Environmental Precautionary Principle, Sociocultural Precautionary Principle, and Economic Precautionary Principle. The UPP notion has the prospect to be a basic instrument for convention, resolutions, decisions, guidelines, strategic plans, and frameworks. Considering the UPP idea, the possibility is that the precautionary principle is used more wisely and strategically in a broader but more specific field.

\section{Indonesia's financial crisis of 1997-1998}

A financial crisis or economic-banking crisis is a phenomenon that often occurs and can create unreasonable panic (Mill 2008). A financial crisis can cause a sovereign country to become bankrupt, even turn a state into a collapse in extreme circumstances (Rousseau 1968). Of the several crises that have occurred, handling financial or banking crises usually requires high costs and the impact caused by the crises. The financial crisis has a huge impact on 
economic activity and can trigger a recession, so with the banking crisis will also make the recession worse (Claessens et al. 2010). In general, the crisis resulted in a significant reduction in various economic factors. After the crisis, the recession period is an empirical fact that the impact is so large that it affects the conditions of consumption, investment, industrial production, employment, exports, and imports.

Financial crises are often associated with substantial changes in the value and amount of credits and prices of assets; disruption in financial intermediation and the availability of external financing for the economy; balance sheet problems on a large scale (be it company, household, financial intermediary and government balance sheets); as well as what form and how much government support (liquidity and recapitalization assistance). Thus, the financial crisis is a multidimensional event, and it is not easy to characterize it using global indicators (Claessens and Kose 2013).

The post-crisis recovery is equally important, given that post-crisis recovery tends to be slow and timeconsuming (long-term effect). A post-financial or banking crisis recovery tends to be slow due to the sluggish domestic market and tight lending.(Kannan et al. 2009) Even in the medium period, the economic growth tended to be depressed significantly after the crisis (Reinhart and Rogoff 2011).

One empirical experience is Indonesia's financial crisis of 1997-1998, a traumatic loss for Indonesia in facing an economic emergency that led to a banking crisis. The 1997-1998 crisis's impact was that the costs incurred to restore the banking sector was high, namely more than Rp. 600 trillion (Hadad et al. 2003). In fact, rescuing the crisis was one of the highest costs of handling the crisis in Asia, which reached $34.5 \%$ of the Gross Domestic Product.(JF 1999) According to Finance Minister Sri Mulyani, the estimated cost of rescue is up to $70 \%$ of the Gross Domestic Product (GDP) (Anon 2016).

The financial crisis that became a banking crisis that hit Indonesia in 1997-1998 was the worst in Indonesia's New Order history. The crisis began with the fall in the value of the Thai baht and the Thai government's failure to maintain the value of the bath. In a relatively short time, the fall in the bath value spread and was followed by the fall in the value of the currencies of several Asian countries, such as Malaysia, Indonesia, the Philippines, Korea, and Hong Kong triggered economic chaos in Asia.

After the Thai currency fall in July 1997, respectively Malaysia, Indonesia, Singapore, the Philippines, and Korea experienced asset deflation of $40 \%$ to $70 \%$ (Wolf 2002) and currency depreciation of $18 \%$ to $85 \%$ (Montes 1999). Pressure on regional markets has intensified in line with the impact of the devaluation of the Thai bath. Regional stock exchanges were also volatile, spreading to neighboring countries of Thailand (Malaysia, Indonesia, Singapore, and the Philippines), resulting in the fall of the Korean won (Baig and Goldfajn 1999). Of several countries in Southeast Asia, Indonesia experienced asset deflation of $40 \%$ to $70 \%$, and the rupiah depreciated by 83.6\%. The rupiah exchange rate against the US dollar experienced a free fall, from Rp. 2,432.00 on July 1, 1997, to Rp. $14,800.00$ on January 24, 1998 (Montes 1999).

\subsection{Financial crisis to become a banking crisis}

In Indonesia's case, one of the triggers for the financial crisis to become a banking crisis was the closure of 16 commercial banks by the Indonesian government and the IMF in November 1997. At the closure of 16 failed banks, the government only guaranteed bank liabilities to small depositors, which was limited to Rp 20,000,000 - (twenty million rupiah) per depositor per bank. Failure to implement a blanket guarantee scheme has resulted in a collapse of public trust, caused tremendous panic, and led to massive withdrawals of deposits (bank runs). The government's response to the onset of the crisis is considered to have damaged international confidence in the rupiah (Sherlock 1998). The political turmoil and riots further exacerbated the situation in May 1998. After the May 1998 riots, public trust in banking fell dramatically, depositors rushed out and made banking conditions in Indonesia worse. As a result, the financial crisis was unbearable; this impacted the economic sector and developed into a banking crisis.

Overall, Indonesia's strategy for dealing with the 1997-1998 banking crisis was divided into 5 (five) stages: First, maintain the exchange rate and prevent banking crises through a tight monetary policy and provide a stimulus package. Second, banking rescue, to resolve liquidity and solvency problems with the Bailout strategy (BLBI). Third, increase public trust and prevent capital flights, with a government guarantee program in the form of a blanket guarantee. Fourth is banking restructuring, by establishing IBRA, restructuring credit, and carrying out bank recapitalization. The fifth is to restore and strengthen banking and financial systems by establishing LPS and OJK and creating a financial safety net. On the whole, the strategy's implementation is accompanied by a more comprehensive reform of laws and regulations, especially in the legal framework and working procedures for financial sector institutions.

Indonesia's financial crisis is an example of an empirical event of how a crisis that was originally quantitative in nature (inflation, a fall in the value of the currency) qualitatively turns into a banking crisis, which forced the government to intervene. 


\subsection{Legal gaps in Indonesia's financial crisis of 1997-1998}

The legal gaps in the financial crisis of 1997-1998 covered the following matters and functions; First, Bank Indonesia had limited autonomy and contingent authority, which was fully under the Monetary Board's control. Second, the banking sector statutory provisions limit the authority and independence of Bank Indonesia. Based on Law 13 of 1968 and Law 7 of 1992, Bank Indonesia was not independent in banks' development and supervision. The position of Bank Indonesia, which was still part of the government, should facilitate coordination with the Minister of Finance, but this was not the case. Rigid banking sector provisions in the process have created problems of legal certainty (supervision and guidance system) and benefits. Even more, based on Law 7 of 1992, banking regulations were carried out for and on behalf of and based on the Minister of Finance decision. Bank Indonesia only implements and/or provides recommendations to the Minister of Finance.

Third, Law No. 13 of 1968 did not provide many alternatives for Bank Indonesia in mitigating problems with banks experiencing liquidity difficulties. Mitigating is limited by providing credit to banks to overcome liquidity problems it faces in an emergency (Bank Indonesia as the lender of last resort). Likewise, Law No. 14 of 1967 concerning Banking Principles does not provide an adequate legal framework regarding what actions to take if a bank experiences a dangerous situation or can endanger solvency or liquidity.

Fourth, the money deposit guarantee at the bank was not implemented properly. In 1973, Indonesia already had Government Regulation No. 34 of 1973, which regulates the guarantee of money deposits at banks whose operations are assigned to Bank Indonesia. However, from 1973 until the financial crisis's threat in 1997-1998, the implementation of Government Regulation No. 34 of 1973 was not heard. Besides, Government Regulation No. 34 of 1973 was not designed to face the threat of a banking crisis. This can be clearly seen from several provisions of the articles, which are limited to how to deal with banks' liquidity problems without regulating the problem of systemic bank failures.

Fifth, Banking law number 7 of 1992 did not yet have sufficient legal principles in banking rescue and restructuring. The legal gaps include how the institutional framework, coordination, communication between competent authorities, and supporting activities make policies. Financial sector policymakers need to improve the institutional framework between them. These institutions' role is very significant; all the policies they take will affect the market and impact the economy.

Sixth Prevention and or mitigating emergencies that are dangerous to the financial system and/or the banking system. A lex specialist law oriented to the sovereignty, necessary, concrete, and important conditions (conditions of necessity, concreteness, and urgency) was needed (Schmitt 2005). Considering the constraints and objectives of extraordinary circumstances, the government needs an extra-judicial rule of law. Those are manifested by forming a special agency to restructure the national financial or banking system. This special agency must have lex specialist and extra-judicial powers. The agency shall be authorized to take countermeasures that are more effective and efficient in a crisis. There can be concrete new legal provisions in an emergency, which are different from the law that applies under normal conditions. Allowing the executive body to gain more specific effective and efficient powers to prevent further damage and restore the situation. The framework for preventing and mitigating emergencies also includes coordination between institutions or authorities in the financial sector at the policy-making level.

How to fill the legal gaps has actually been a concern since the days of the Roman Empire. At that time, the jurists paid great attention into two things; the first is the authority or who has the right to fill or overcome it. The second is the method or how to fill the legal gap. The easiest and best way to fill the legal gap is to make the necessary laws. In other words, if the applicable law cannot provide the required legal norms, then a legal rule or regulation is formed to regulate the legal issue concerned. If the prevailing laws and regulations do not completely regulate a legal issue, then a new provision is added to the statutory regulation. Additional provisions can be in the form of addendums or amendments to legal or regulatory requirements. Law may remain in effect even though changes in one or two of its articles have a new meaning by concrete needs. However, sometimes there are no laws and regulations that regulate a legal issue, and it is not possible to make new laws.

In principle, the formation and/or addition of the law is carried out by the legislature. The formation and/or addition of the law requires a process and time. In contrast, decisions must often be made in certain emergency circumstances with limited time and objectivity. The function of the legislature cannot always act to compensate for these conditions. On the other hand, the legislature cannot foresee and determine the cases that may be faced. With the increasing need and emergency pressure to overcome the legal gaps, more effective and efficient action is needed besides the legislature. In response to this, the executive body's role will be significant because legal gaps can be filled with executive discretions for the state's and society's good.

\section{Overcoming the financial crisis with the precautionary principle}

As discussed above, in certain circumstances the law is utterly inadequate, but decisions and actions must be taken. To overcome this problem, it must be left to the discretion of the executive power, to be realized for the good of the state and society (Gross and Ní Aoláin 2006). Likewise, if there is a threat of a financial crisis and there is no 
adequate legal framework to deal with it, the government as an executive body must make decisions and act immediately for the good of the state and society. Financial or economic crises have been identified as similar to violence or physical criticalness threatening the state and society, leading the executive body to require extra powers to overcome the threat. According to Locke, the prerogative is nothing but the power in the executive's hands to provide for the public interest, which is subject to unforeseen and uncertain circumstances, and when laws cannot provide certainty appropriately (Locke 2003).

This is what actually happened during the 1997-1998 financial crisis in Indonesia. Before the threat of the 1997-1998 Financial Crisis, Indonesia did not yet have laws and regulations that specifically regulate the mechanism of action that must be taken in facing the threat of a financial and/or banking crisis. The laws and regulations that were in force in the financial sector at that time were very limited and inefficient in their implementation. This situation creates problems and gaps between existing regulations and an urgent need. It was an issue that needs to be formulated as a set of rules to overcome the crisis.

At the beginning of the crisis, the Indonesian government took certain steps that were deemed good for society and the state. Despite this fact, the government was unprepared and less alert because Indonesia did not have a legal umbrella to guide it in facing the threat of a financial system crisis. All government efforts and actions were carried out based on discretion, which, although well-intentioned, was inefficient and tended to fail. First, this can be seen from the government's failure to read the Thai baht currency crisis signs. The signs of a currency crisis in Thailand actually began to be felt in 1996, becoming obvious between March 1997 and July 1997. Thailand's economy became sluggish when, in 1996, Thailand experienced a 5-30\% housing vacancy rate (Lauridsen 1998). The recession is increasingly visible when the bad credit figures increase to impact banks and lending companies. Moreover, it turns out that these banks and companies also receive loans from abroad. Over the course of six years, Thailand's total debt increased from 34\% of GDP to 51\% of GDP in 1996 (Lauridsen 1998).

Second, from the government's initial response to issuing a package of economic policies. Before the first IMF's LoI, the package was issued without being accompanied by a policy formulation of crisis prevention and management regulations. At that time, the government was too focused on maintaining the rupiah exchange rate. On August 14, 1997, the government released the Rupiah exchange rate against the US dollar to the market mechanism. On September 3, 1997, the government issued an economic policies package covering the monetary and fiscal sectors and the real sector. The policy package took the form of trade liberalization and rescheduling of government projects.

Third, the government failed to prevent a banking crisis due to the collapse of depositor confidence after the closure of 16 national private banks. At the closure of 16 national private commercial banks, the government and the IMF only calculated the total assets of 16 banks, which only amounted to $3 \%$ of total banking assets. Judging from the small number of assets, the closure is not expected to impact depositor confidence and will not be rushed (Bank Indonesia 2010). The panic was unavoidable, the trust in banking was a collapse, and irrational actions have happened; customers withdraw their funds. The chaotic financial crisis was becoming a banking crisis.

With the problems of legal gaps in the economic and banking sectors, the government was required to respond quickly during the 1997-1998 financial crisis. The government did not have many options to stabilize the rupiah's value and make the banking sector healthy. Overall, the government has taken several actions, namely: 1) Sign LoI with IMF; 2) Revoked licenses and closed 16 private commercial banks; 3) Guarantee funds of up to IDR 20 million per depositor per bank; 4) Undertaking to restructure of troubled financial institutions that deserve; and 5) Improve the institutional, legal, and regulatory framework for the banking sector. The actions were not based on a legal framework for emergencies, urgent and occasional demand in its implementations. The absence of such a legal framework had impacted the technical coordination and exchange of information between Bank Indonesia and the Ministry of Finance and how to formulate appropriate policies for crisis resolution.

In the first LoI with IMF of October 31, 1997, the Indonesian government at last firmly stated it would improve the institutional, legal, and regulatory framework for banking operations. The laws and decrees governing central bank and banking operations, bank liquidation, legislation, judicial and administrative agencies for title registration, collateral perfection, foreclosure, and bankruptcy will be revised to incorporate international best practices. Furthermore, foreign ownership of Indonesian financial institutions will be facilitated for international banks and foreign investors.

From the description above, the government has actually done was for the good of the state and society, even without any appropriate regulatory or legal frameworks. It could be argued that the government was using its prerogative power to act. Furthermore, the steps were taken by the government actually reflect the considerations and elements of the precautionary principle. The financial crisis can be categorized as a dangerous threat with a severe effect from the basic understanding of the precautionary principle.

Likewise, there were high conditions of uncertainty, which are difficult to predict. On May 30, 1997, Indonesia's macroeconomic indicators showed a positive increase in performance. GDP increased by $7.8 \%$, the inflation rate fell to $6.47 \%$, foreign exchange reserves increased by USD 4 billion (World Bank 1997). At that time, Indonesia had fulfilled the five main factors to maintain high growth and improve equity in Asia. A healthy 
macroeconomy that is considered capable of absorbing shocks, high domestic investment and savings, strong human resource development, attention to international competition, reduced interference to the market, and the last is government institutions and institutions' improvement. Indonesia got a BBB rating from Standard and Poor's but became BBB- on October 10, 1997 (Bank Indonesia 2014). However, no economist expected that strong macroeconomic conditions would collapse in just 3 months. From the basic understanding of the precautionary principle, this macroeconomic condition is also categorized as a situation of uncertainty that causes a threat of crisis and its impact in short to long term consequences.

Since there were a financial crisis threat and uncertainty, the third basic understanding of the precautionary principle related to the threat of a financial crisis is the element of preventive action. Preventive action must be taken immediately, whether by limiting certain actions or immediately taking certain actions. All those three elements are the government's responsibility to take action to overcome the threat of crisis. The action of government is an obligation for the good of the state and society.

From the author's perspective, the precautionary principle is unique and has at least three significant roles in common that most supporters of the precautionary principle generally fit. First, as an approach to avoid the serious damage or dangerous risks due to a threat. Second, as a response to uncertain critical situations. Third, as a guide in dealing with a catastrophic state.

\section{Conclusion}

As described above, this article is an initial study of how to apply the precautionary principle in dealing with the threat of a financial crisis. The author emphasizes that if there is a threat of a financial crisis and there is no regulatory framework, the government can act to use its authority for the good of the state and society by applying the primary understanding of the precautionary principle as a guide.

Using Indonesia's empirical experience in dealing with the threat of a crisis in 1997-1998, It can be seen that the precautionary principle can actually be used to fill legal gaps. However, it needs to be addressed wisely and carefully in its application, especially by the executive body, where an attitude of caution is very reasonable. The precautionary principle to be applied cannot be found only through the text but also requires reasoning and understanding of values and meanings, since it is rooted in society, manifested in values used as guidelines by the executive body. This is where it becomes important to understand the true value and meaning of the precautionary principle.

Applying the precautionary principle is considered important because its application is expected to complete existing legal norms. The precautionary principle in law is not the law in a concrete sense, but rather the basics in forming positive legal rules, complement the law and legal system so that the law can apply more dynamically.

The authors conclude that a basic understanding of the precautionary principle is very likely to be applied if there is a legal gap in facing the threat of a financial crisis. The precautionary principle can be used to oversee decision-making, as a guide, and as an element to develop government institutions' capacity to overcome a financial crisis. The author also finds that the executive's utilitarianism and prerogative authority theory greatly influences the development process to apply the precautionary principle as a guideline. In the end, the author suggests that the notion for applying the precautionary principle within the prerogative power of the executive body shall be explored and needs further study.

\section{References}

Akins, A. et al. (2019). The universal precautionary principle: New pillars and pathways for environmental, sociocultural, and economic resilience. Sustainability (Switzerland), 11(8).

Anon. (2016). Sri Mulyani: Ongkos Penanganan Krisis RI Termahal di Dunia. [online]. Available from: https://www.cnnindonesia.com/ekonomi/20160922130207-78-160256/sri-mulyani-ongkos-penanganankrisis-ri-termahal-di-dunia/ [Accessed November 17, 2017].

Baig, T. and Goldfajn, I. (1999). Financial Market Contagion in the Asian Crisis. , 46(2), pp.167-195.

Bank Indonesia. (2014). Historical Indonesia Sovereign Rating. [online]. Available from: https://www.bi.go.id/en/iru/market-data/indonesian-sovereign-rating/Contents/Rating Table May 2014.pdf [Accessed July 8, 2020].

Bank Indonesia. (2010). Krisis Global Dan Penyelamatan Sistem Perbankan Indonesia. Jakarta: Bank Indonesia. Bourguignon, D. (2015). The Precautionary Principle, Definitions, applications and governance. European Parliamentary Research Service.

Brody, H. et al. (2000). Map-making and myth-making in Broad Street: The London cholera epidemic, 1854. Lancet, 356, pp.64-68. [online]. Available from: http://ovidsp.ovid.com/ovidweb.cgi?T=JS\&PAGE=reference\&D=emed5\&NEWS=N\&AN=2000225948.

Cameron, J. and Abouchar, J. (1991). The Precautionary Principle: A Fundamental Principle of Law and Policy for the Protection of the Global Environment. Boston College International and Comparative Law Review, 14(1), pp.1-27. 
Claessens, S. and Kose, M.A. (2013). Financial Crises: Explanations, Types, and Implications.

Claessens, S., Kose, M.A. and Terrones, M.E. (2010). The global financial crisis: How similar? How different? How costly? Journal of Asian Economics, 21(3), pp.247-264.

Cross, F.B. (1996). Paradoxical Perils of the Precautionary Principle. Washington and Lee Law Review, 53(3).

DeFur, P.L. and Kaszuba, M. (2002). Implementing the precautionary principle. Science of the Total Environment, 288(1-2), pp.155-165.

Dinneen, N. (2013). Precautionary discourse: Thinking through the distinction between the precautionary principle and the precautionary approach in theory and practice. Politics and the Life Sciences, 32(1), pp.2-21.

Ellis, J. and FitzGerald, A. (2004). The Precautionary Principle in International Law: Lessons from Fuller's Internal Morality. McGill Law Journal, 49.

Fisher, E., Jones, J. and von Schomberg, R. (2006). Implementing the Precautionary Principle: Perspectives and Prospects. In E. Fisher, J. Jones, \& R. von Schomberg, eds. Implementing the Precautionary Principle: Perspectives and Prospects. Northhampton: Edward Elgar Publishing, Inc.

Gollier, C. and Treich, N. (2003). Decision-Making under Scientific Uncertainty: The Economics of the Precautionary Principle. Journal of Risk and Uncertainty, 27(1), pp.77-103.

Gross, O. and Ní Aoláin, F. (2006). Law in times of crisis: Emergency powers in theory and practice. New York: Cambridge University Press.

Hadad, M.D., Santoso, W. and Arianto, B. (2003). Indikator Awal Krisis Perbankan. International Forestry Review, $5(2)$.

Harremoes, P. et al. (2001). Late lessons from early warnings: the precautionary principle 1896-2000.

International Monetery Fund. (1997). Memorandum on Economic and Financial Policies between Indonesia and IMF. [online]. Available from: https:/www.imf.org/external/np/loi/103197.htm [Accessed April 2, 2019].

JF, L. (1999). The Stability of the Financial System. Reverse Bank of Australian Bulletin.

Kannan, P., Scott, A. and Terrones, M.E. (2009). From Recession to Recovery: How Soon and How Strong. World Economic Outlook.

Kessler, R. (2011). Engineered nanoparticles in consumer products: understanding a new ingredient. Environmental health perspectives, 119(3).

Lauridsen, I. (2013). Precautionary Action, A Study on the Status and Implications of the Precautionary Principle in International Environmental Law. Lund University.

Lauridsen, L.S. (1998). The Financial Crisis in Thailand: Causes, Conduct and Consequences? World Development, 26(8), pp.1571-1591.

Locke, J. (2003). Two Treatises of Government and A Letter Concerning Toleration. I. Shapiro, ed. New Haven, Connecticut: Yale University Press.

Martinez-Diaz, L. (2006). Pathways through financial crisis: Indonesia. Global Governance, 12(4), pp.395-412.

Mill, J.S. (2008). Principles of Political Economy with Chapters on Socialism. J. Riley, ed. New York: Oxford University Press.

Montes, M.F. (1999). The Currency Crisis in Southeast Asia. Singapore: Institute of Southeast Asian Studies.

Peterson, M. (2007). The precautionary principle should not be used as a basis for decision-making. Talking Point on the precautionary principle. EMBO Reports, 8(4), pp.305-308.

Reinhart, C.M. and Rogoff, K.S. (2011). This Time Is Different, Eight Centuries of Financial Folly. New Jersey: Princeton University Press.

Rousseau, J.-J. (1968). The Social Contract. M. Cranston, ed. London: Penguin Books Ltd.

Sabhlok, S. (2019). Why the precautionary principle is bad policy. [online]. Available from: https://timesofindia.indiatimes.com/blogs/seeing-the-invisible/why-the-precautionary-principle-is-badpolicy/ [Accessed May 5, 2020].

Sandin, P. (2002). The Precautionary Principle : From Theory to Practice. , p.28.

Schmitt, C. (2005). Political Theology: Four New Chapters on the Concept of Sovereignty. G. Schwab, ed. Chicago: The University of Chicago Press.

Sherlock, S. (1998). Crisis in Indonesia: Economy, Society and Politics. [online]. Available from: https://www.aph.gov.au/About_Parliament/Parliamentary_Departments/Parliamentary_Library/Publications _Archive/CIB/CIB9798/98cib13\#CON [Accessed October 5, 2019].

Sunstein, C.R. (2005a). Laws of Fear, Beyond The Precautionary Principle. Cambridge: Cambridge University Press.

Sunstein, C.R. (2005b). The Precautionary Principle as a Basis for Decision Making. The Economists' Voice, 2(2).

United Nations Educational Scientific and Cultural Organization. (2005). Precautionary Principle.

Vanderzwaag, D. (2002). The precautionary principle and marine environmental protection: Slippery shores, rough seas, and rising normative tides. Ocean Development and International Law, 33(2), pp.165-188.

Weiss, C. (2003). Scientific Uncertainty and Science-Based Precaution. International Environmental Agreements: Politic, Law and Economics, 3(2), pp.137-166. 
Wibisana, A.G. (2011). The Development of the Precautionary Principle in International and Indonesian Environmental Law. Asia Pacific Journal of Environmental Law, 14(1/2), pp.169-202.

Wiener, J.B. and Rogers, M.D. (2002). Comparing precaution in the united states and Europe. Journal of Risk Research, 5(4), pp.317-349.

Wolf, C.J. (2002). The End of Asia's Economic Crisis. In Straddling Economics and Politics: Cross-Cutting Issues in Asia, the United States, and the Global Economy. Santa Monica: RAND, pp. 118-124.

World Bank. (1997). Indonesia Sustaining High Growth with Equity. 